\title{
Gross morphological and morphometric studies of oviduct in three genotypes of Nigerian indigenous laying chickens
}

\begin{abstract}
Gross and morphometric studies were carried out on the oviducts of three Nigerian indigenous genotypes of chicken. Fifteen adult laying chickens of three genotypes \{five female per genotype of Normal Feathered (NoF), Naked Neck (Na) and Frizzle Feathered (FF) $\}$ were bought from Mokwa local markets. They were quarantined for two weeks, stabilized for another week, live weights were taken and then slaughtered using Halal method. After careful evisceration, segments of oviduct were examined grossly and then weights, lengths, thickness and width of the segments were obtained. The mean weights, lengths and widths of the infundibulum, magnum, isthmus, uterus, vagina and entire oviduct of the three studied genotypes were not significantly different $(\mathrm{P}>0.05)$ from one another, except the width of uterus $(\mathrm{P} \leq 0.05)$. All the three genotypes have similar gross and morphometric patterns except that the uterus of $\mathrm{Na}$ and FF had significantly $(\mathrm{P} \leq 0.05)$, wider width compared to the NoF. This study in addition to its contribution to the knowledge of comparative avian anatomy up to genotype level, has also established a comparative baseline data for further gross and morphometric reproductive studies in these genotypes of Nigerian indigenous chickens.
\end{abstract}

Volume 5 Issue 4 - 2017

\author{
Mahmud MA,' Shaba P,' Onu JE, ${ }^{2}$ Sani SA, ${ }^{3}$ \\ Danmaigoro A, ${ }^{3}$ Abdulsalam W,' MaajiM,' \\ Mohammed AA' \\ 'Department of Animal Health and Production Technology, \\ Niger State College of Agriculture, Nigeria \\ ${ }^{2}$ Department of Veterinary Anatomy, Michael Okpara University \\ of Agriculture, Nigeria \\ ${ }^{3}$ Department of Veterinary Anatomy, Usmanu Danfodiyo \\ University, Nigeria
}

Correspondence: Muhammad Abdullahi Mahmud, Department of Animal Health and Production Technology, Niger State College of Agriculture, Mokwa, Niger State, Nigeria, Tel +2348 0363 47603,Email drmahmud2@gmail.com

Received: October 27, 2016 | Published: June 27, 2017

Keywords: morphology, morphometry, genotypes, local chicken

Abbreviations: NoF, normal feather chicken; Na, naked neck chicken; FF, frizzle feather chicken

\section{Introduction}

The Nigerian indigenous chickens play major roles not only in rural economics but also contribute substantially to the gross national product. ${ }^{1}$ They have remained predominantly in villages because of their inherent advantages over the exotic breed. Most of the birds are kept in small flocks under a scavenging system and the feed resources for the birds are household refuse, homestead pickings, crop residues, herbage, seeds, green grasses, earthworms, and small amount of supplemented feeds offered by the flock owner. They are well adapted to the adverse climatic conditions of the tropical environment and low management inputs. They contain a highly conserved genetic system with high levels of heterozygosity. ${ }^{2}$ These indicate that they are highly important farm animals, kept for good source of animal protein, for income and socio-cultural roles. Momoh et al. ${ }^{3}$ reported the adaptive potentials of the Nigerian indigenous chicken to varied ecological conditions, stresses and diseases. One of these adaptive potentials is the ability to produce a reasonable number of eggs when compared to their counterpart hybrids raised under intensive conditions. The Nigerian local chickens (naked neck, frizzled and normal feathered) constitute about $80 \%$ of the 120 million poultry birds. These varieties, particularly the naked neck have been reported to possess a good egg laying characteristics. ${ }^{4}$ Since the success of the local chicken enterprise depends on the total number of quality eggs produced, ${ }^{5}$ and then understanding the normal morphology of the oviduct of these local chickens becomes paramount. The chicken oviduct is a tubular organ responsible for the secretion of the components surrounding the yolk and transport of the egg. Functional and healthy oviduct is essential for both quantity and quality of egg. ${ }^{6}$ Any disorder that affects the reproductive system will have a great bearing on production potential and incur a heavy loss. The female genital apparatus of the chicken is composed only of the left ovary and oviduct. The oviduct is a highly convoluted, muscular duct, which is suspended from the left side of the abdominal cavity by the dorsal ligament. ${ }^{7}$ The oviduct consists of five distinct regions the infundibulum, the magnum, the isthmus, the shell gland (or uterus) and the vagina. ${ }^{8}$ Major genes effect on growth, fertility, hatchability and semen quality characteristics have also been reported. ${ }^{9-12}$ Wekhe ${ }^{13}$ earlier reported that Nigerian indigenous chickens are more resistant to infectious disease agents than their exotic counterparts. While there are reports in the literature about growth, fertility, hatchability, reproductive performance and semen quality of the Nigerian indigenous chicken, reports on genotype/ strain differences on the gross morphology and morphometry of their oviducts are scanty. Therefore, this study was undertaken to highlighting terms of gross morphology and morphometry, the oviducts gross architectural differences or similarities in the three Nigerian genotypes of Chicken.

\section{Materials and methods}

The present study was conducted in the Anatomy Laboratory, Department of Animal Health and Production Technology, Niger State College of Agriculture, Mokwa, North Central, Nigeria. Mokwa is located at latitude $9^{\circ} 17^{\prime} 38^{\prime \prime}$ North and longitude $5^{\circ} 3^{\prime} 16$ East. ${ }^{14}$ Fifteen apparently healthy adult laying local chicken genotypes (five per genotype of Normal Feathered (NoF), Naked Neck (Na) and Frizzle Feathered (FF)) were purchased from local markets in Mokwa. They were quarantined for two weeks and then stabilized for another two weeks in a pen at the poultry unit, livestock farm of the College. They were fed commercial layer diet (Animal Care ${ }^{\circledR}$ feed) within these periods and water ad libitum under a good management practice. At 
the end of these periods, all birds were fasted for 12 hours, live body weights were recorded and then all of them were slaughtered using Halal method ${ }^{15}$ of slaughtering. They were allowed to bleed for two (2) minutes before been de-feathered. Organs were noted in situ and then were eviscerated. The photographs were taken before evisceration and afterwards. The oviducts were collected for gross and morphometric studies. The location, shape, size, weight, length, thickness and width of the segments were considered for the studies. The photographs were made using digital camera (Samsung ES95, 16.2 megapixels). The weight $(\mathrm{g})$, length $(\mathrm{cm})$, thickness $(\mathrm{cm})$ and width $(\mathrm{cm})$ were measured using a weighing balance (Shimadzu AW320, Germany), meter rule, digital Vernier caliper and thread respectively. The oviduct data obtained were expressed as Mean \pm SEM (Standard Error of Mean) and subjected to statistical analysis using Statistical Package for the Social Sciences (SPSS) version 17.0. One-Way Analysis Of Variance (ANOVA) at $95 \%$ confidence interval (CI) was used to determine the level of significant difference in mean values among the three genotypes. Values of $(\mathrm{P} \leq 0.05)$ were considered significant. Where there were differences in means, they were separated by Tukey's Honestly Significant Difference (HSD).

\section{Result}

\section{Gross morphology of oviduct}

The oviduct in the laying NoF (Plate 1), Na (Plate 2) and FF (Plate 3) genotypes appeared to be long, less convoluted, highly vascular tube and occupied the most left side of celom, with five morphologically distinct regions; infundibulum, magnum, isthmus, uterus, and vagina. It is located at the left side of the coelom and appeared as a thin straight-like tube that extended from left ovary to cloaca. It is fixed in situ by a thin doubled fold of serous membrane. This serous membrane is extended as a single layer from the dorsal body wall into the tube of the oviduct. Subsequently, it overlapped around the tube to return back toward the dorsal body wall again forming the dorsal and ventral oviductal ligaments. The first two third of the oviduct is related dorsolaterally to the wall of coelomic cavity, whereas the last third is related to the nearby part of the ureter. The oviduct subsequently opened into cloaca.

\section{Infundibulum}

In all the three species, the infundibulum was the first segment of the oviduct, and further divided into two morphologically distinct areas: the funnel and the neck. The funnel was opened, with a very thin wall and fringed edges that surrounded the left ovary. Caudally, the walls of the funnel became thicker, converged and formed the neck of the infundibulum.

\section{Magnum}

The magnum was the most convoluted part of the oviduct in all the three laying species but most coiled in the NoF than in the remaining two species. The boundary between the magnum and the isthmus was clearly delineated by a narrow translucent zone.

\section{Isthmus}

The isthmus was comparatively narrow than magnum and uterus. The gross morphology of the uterus was different from those of the other segments because it was shaped as a sack, while the other segments were tubular.

\section{Uterus}

The uterus was divisible into the cranial narrow tubular part called pars minor uteri and the main pouch like part called the pars major uteri. The pars major uterus was found to be distensible and the walls appeared not be as thick as those of the magnum or the isthmus. It was thickest and widest of all the five regions in all the three species.

\section{Vagina}

The vagina was the last region of the oviduct. It was straight short tube that opened into the cloaca and showed thickened muscular wall compared to the other segments. The muscular sphincter was found in the vagina, which opened into the cloaca. The vagina appeared to be thickest in the NoF genotype than in the remaining two species.

\section{Gross morphometry of the oviduct}

The results for mean weights, mean lengths and mean widths of segments of the oviduct in the three studied genotypes are presented in Figures 1-3 respectively. The mean live weights, weight of segments of the oviduct, Lengths of segments of the oviduct and Widths of segments of the oviduct (except the uterus), of $\mathrm{No}, \mathrm{Na}$ and FF, were no statistically significantly $(\mathrm{P}>0.05)$ different, from one another in the three genotypes.

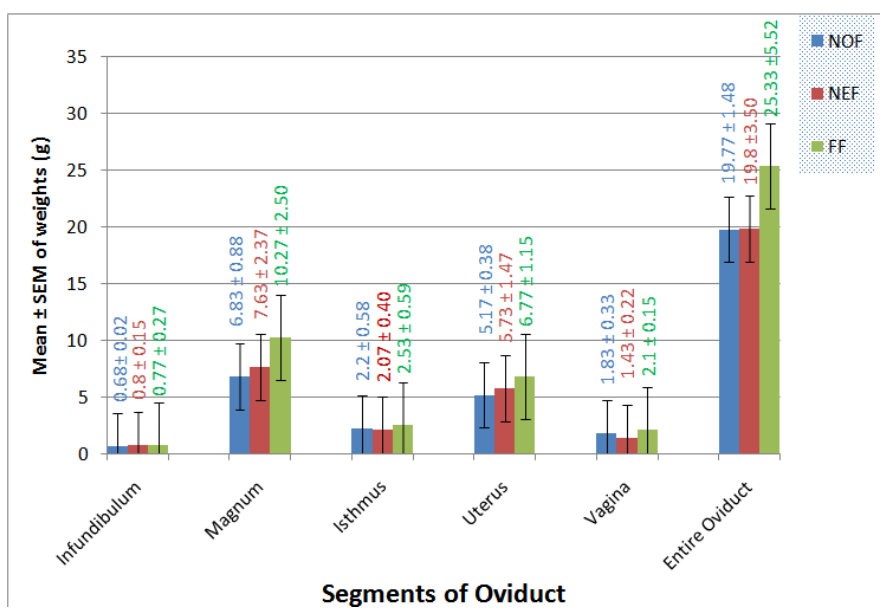

Figure I Comparison of the weights (g) of segments of the oviduct in the normal feathered, naked neck and frizzle feathered genotypes of Nigerian indigenous chickens.

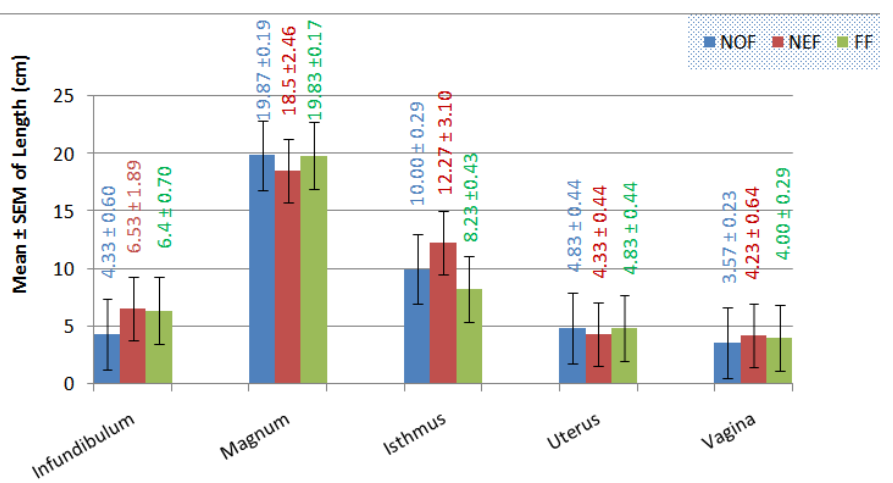

Segments of Oviduct

Figure 2 Comparison of the lengths $(\mathrm{cm})$ of segments of the oviduct in the normal feathered, naked neck and frizzle feathered genotypes of Nigerian indigenous chickens. 


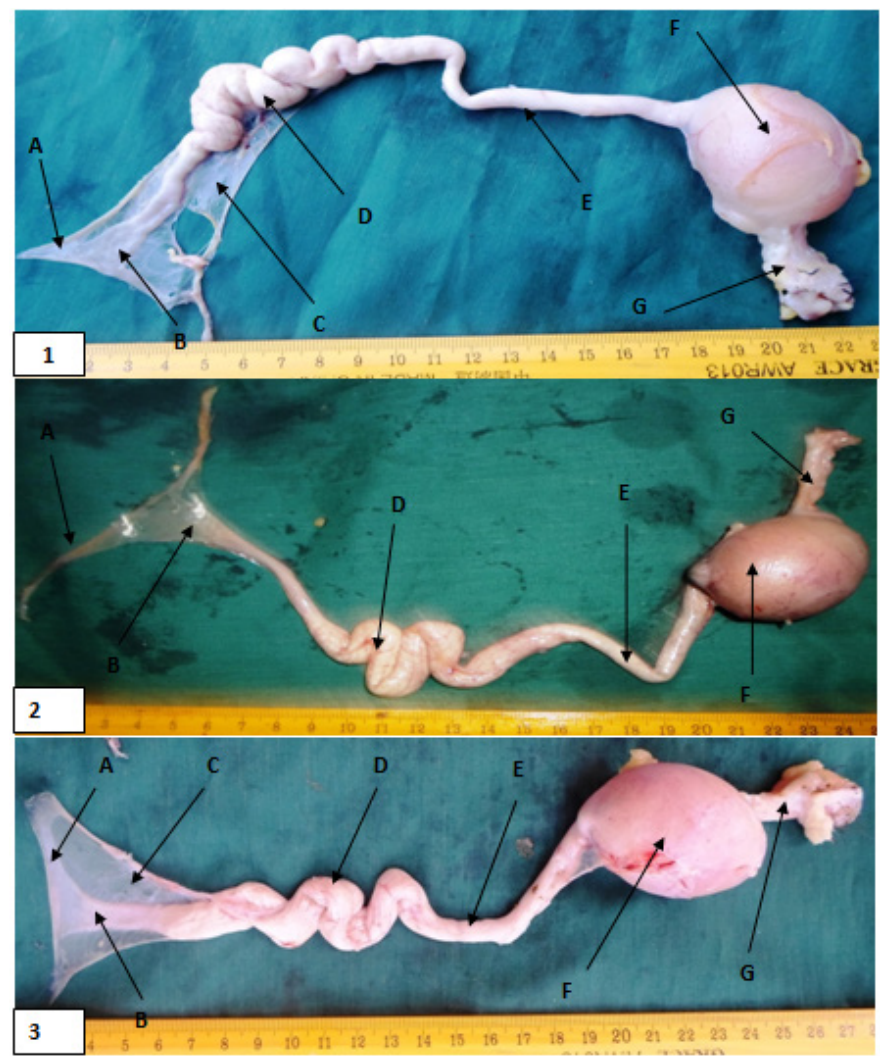

Plate I, Plate 2, Plate 3 Photographs of oviduct of normal feathered (I), naked neck (2) and frizzle feathered (3) Nigerian indigenous chickens. A, Infundibulum (Funnel); B, Infundibulum (Neck); C, ligament; D, Magnum; E, Isthmus; F, Uterus; G, Vagina

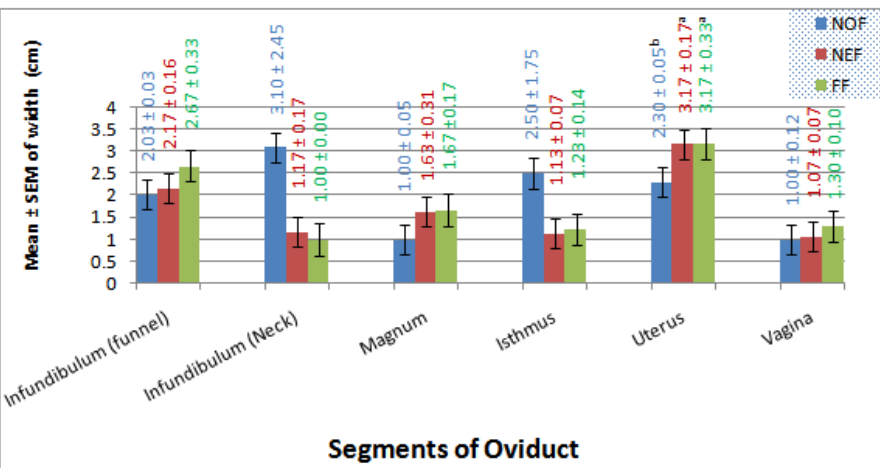

Figure 3 Comparison of the widths $(\mathrm{cm})$ of segments of the oviduct in the normal feathered, naked neck and frizzle feathered genotypes of Nigerian indigenous chickens.

\section{Discussion}

The current findings of oviduct which appeared to be long, less convoluted, highly vascular tube and occupied the most left side of celom are similar to those recorded by Khokhlov RY ${ }^{16}$ They reported that the oviduct of the hen was well-developed at the left side, atrophied at the right side and consisted of all five regions as described in the present study. However, the finding disagrees with reports of ${ }^{17,18}$ who reported presence of both oviducts in falconiformes and in brown kiwi. The finding of the present study on division of the oviduct into five distinct regions had been previously documented by
Khokhlov RY ${ }^{16}$, Pollock CG, ${ }^{19}$ Sharaf ASM,,${ }^{20}$ Moraes C et al. ${ }^{21}$ Vijaya kumar $\mathrm{K}$ et al. ${ }^{22}$ They all documented that the oviduct in most of birds is constructed of only five different regions. The present finding however, is not in agreement with the reports in Muscovy duck by Fujii $\mathrm{S}^{23}$ who considered the fimbriated part as a dependent region, and reported that the left oviduct comprised six anatomically and functionally different regions.

The presence of right oviduct is not recorded in the present study. In contrast to the present findings, ${ }^{24}$ identified a moderately developed right oviduct measuring $4 \mathrm{~cm}$ in length in domestic duck and ${ }^{25}$ reported rudimentary right oviduct with infundibulum and magnum alone in fowl. The current finding on the location and attachments of the oviduct are comparable to those recorded by Sharaf $\mathrm{ASM}^{20}$, AlKarkhy, ${ }^{26}$ Parto P, ${ }^{27}$ Ferdous KA. ${ }^{28}$ They reported that the oviduct in all birds is attached to the celom by a thin double fold of dorsal and ventral oviductal ligaments. However, the current finding is contrary to the earlier reports of Parizzi $\mathrm{RC}^{29}$ in rhea bird, who divided the oviductal ligaments into three named ligaments according to the fixed region of the oviduct.

The two parts observed in the infundibulum of the three species in the present study were previously recorded in other species. ${ }^{20,26-28}$ The present finding is however contrary to the reports of ${ }^{30}$ in Brown Kiwi bird, that the funnel was very wide to receive the ovum from both left and right ovary. It is also contrary to the earlier reports on the infundibulum of laying hen by Bakst $\mathrm{MR}^{31}$ who said that three parts are found; funnel, neck and fimbriae.

The current finding on the funnel shaped part, which was opened towards the left ovary is similar to the previous descriptions made on laying adult emu birds' oviduct by Vijayakumar $\mathrm{K}^{22}$ the ratite oviduct by Drenowatz $\mathrm{C}^{32}$ and the domestic fowl oviduct by Fowler ME. ${ }^{33}$ These reports indicated that the infundibulum opened by an ostium that lead into the first portion of the oviduct.

The subdivision of the uterus in the present study into cranial narrow tubular part called pars minor uteri and the main pouch like part called the pars major uteri confirmed similar findings observed in the uterus of hens, ${ }^{34}$ turkey $^{27,34}$ in ostrich ${ }^{35}$ and geese. ${ }^{26}$ The mean live weights for $\mathrm{No}, \mathrm{Na}$ and $\mathrm{FF}$ of $879.33 \pm 50.74 \mathrm{~g}, 847.33 \pm 29.06 \mathrm{~g}$ and $849.67 \pm 74.44 \mathrm{~g}$ respectively reported in this study were lower than the mean values of $100.50 \pm 25.01 \mathrm{~g}, 898.00 \pm 20.11 \mathrm{~g}$ and $908.00 \pm 31.41 \mathrm{~g}$ earlier reported by Peters SO et al. ${ }^{36}$ in matured No, Na and FF genotypes respectively that had undergone at least one breeding cycle. Also, they are lower than the live weight values reported by Peters SO et al. ${ }^{36}$ in Nigerian native chickens,${ }^{37}$ in Nigerian local breed of chicken and ${ }^{38}$ for indigenous scavenging chickens in Ethiopia. They were however within the range reported by Gueye $\mathrm{EF}^{39}$ for chickens in Africa $a^{40} d^{40}$ for family rural chickens in East Asia. This difference might be due to climatic or nutritional factors.

The various mean weights, lengths and widths of the infundibulum in $\mathrm{NoF}, \mathrm{Na}$ and $\mathrm{FF}$ genotypes obtained in the present study are similar to those recorded in others birds such as turkey ${ }^{27}$ and duck. ${ }^{41}$ However, the length values are higher than that mentioned for duck (Tsai-ya) ${ }^{42}$ and in mature geese. ${ }^{26}$ Also, the mean weight and length values obtained in this study are lower than what was obtained by Khokhlov $\mathrm{RY}^{16}$ in mature hens and ${ }^{43}$ in local Deshichickens of Bangladesh. These differences could be due to species variations. The statistical analysis showed that the magnum in the three species was the longest region of the oviduct; and such character may be related to the capacity of 
this region in production and secretion of thick albumen layer, which constitute the bulked layer of the egg.

The mean magnum weights of $6.83 \pm 0.88 \mathrm{~g}, 7.63 \pm 2.37 \mathrm{~g}$ and $10.27 \pm 2.50 \mathrm{~g}$ in NoF, Na and FF genotypes respectively obtained in the present study are lower than the mean magnum weight of $11.50 \pm 1.73 \mathrm{~g}$ recorded by Mishra D et al. ${ }^{43}$ in local Deshi chickens of Bangladesh. However, the mean magnum lengths obtained in the present study are similar to what they obtained. These differences could be due to breed variation. The statistical analysis showed that the isthmus is the second longest region of oviduct, next to the magnum in three studied species. Physiologically, this region is associated with synthesis of the thin albumen of the egg. The mean isthmus weights of $2.20 \pm 0.58 \mathrm{~g}$, $2.07 \pm 0.40 \mathrm{~g}$ and $2.53 \pm 0.59 \mathrm{~g}$ in $\mathrm{NoF}, \mathrm{Na}$ and FF respectively as obtained in the present study are lower than the mean isthmus weight of $2.78 \mathrm{~g}$ earlier obtained by Mishra D et al. ${ }^{43}$ in local Deshichickens of Bangladesh.

The mean isthmus lengths of $10.00 \pm 0.29 \mathrm{~cm}, 12.27 \pm 3.10 \mathrm{~cm}$ and $8.23 \pm 0.43 \mathrm{~cm}$ in No, Na and FF respectively and widths of $2.50 \pm 1.75 \mathrm{~cm}, 1.13 \pm 0.07 \mathrm{~cm}$ and $1.23 \pm 0.14 \mathrm{~cm}$ in $\mathrm{No}, \mathrm{Na}$ and $\mathrm{FF}$ respectively obtained in the present study are similar to the earlier reports of ${ }^{17}$ in laying hens. They reported isthmus was short and slightly reduced in diameter and the length ranged from about 4 to $12 \mathrm{~cm}$, with a mean length and diameter of about $8 \mathrm{~cm}$ and $1 \mathrm{~cm}$, respectively. The mean uterus weights $(5.17 \pm 0.38 \mathrm{~g}, 5.73 \pm 1.47 \mathrm{~g}$ and $6.77 \pm 1.15 \mathrm{~g}$ in No, Na and FF respectively) and lengths $(4.83 \pm 0.44 \mathrm{~cm}$, $4.33 \pm 0.44 \mathrm{~cm}$ and $4.83 \pm 0.44 \mathrm{~cm}$ in $\mathrm{No}$, Na and FF respectively) of the three studied species obtained in the present study are lower than the mean uterus weight $(6.80 \pm 1.32 \mathrm{~g})$ and length $(6.10 \pm 2.80)$ by Mishra $\mathrm{D}$ et $a 1 .{ }^{43}$ in local Deshi chickens of Bangladesh. This difference could be due to breed variation. The mean vagina weights $(1.83 \pm 0.33 \mathrm{~g}$, $1.43 \pm 0.22 \mathrm{~g}$ and $2.10 \pm 0.15 \mathrm{~g}$ in No, Na and FF respectively) and lengths $(3.57 \pm 0.23 \mathrm{~cm}, 4.23 \pm 0.64 \mathrm{~cm}$ and $4.00 \pm 0.29 \mathrm{~cm}$ in No, Na and FF respectively) of the three studied species obtained in the present study are lower than the mean vagina weight $(2.28 \pm 0.457)$ and length $(6.83 \pm 2.82)$ earlier reported by Mishra $\mathrm{D}$ et al..$^{43}$ in local Deshi chickens of Bangladesh. Furthermore, the length and width of vagina in the present study are shorter than those of adult ISA-brown chicken, ${ }^{28}$ in ostrich ${ }^{20}$ and in turkey. ${ }^{44}$

\section{Conclusion}

The mean weights, lengths and widths of the infundibulum, magnum, isthmus uterus, vagina and entire oviduct of three genotypes studied were not significantly different $(\mathrm{P}>0.05)$ from one another, except the width of uterus $(\mathrm{P} \leq 0.05)$. All the three genotypes have similar gross and morphometric patterns except that the uterus of $\mathrm{Na}$ and FF had significantly ( $\mathrm{P} \leq 0.05)$, wider width compared to the NoF. This study in addition to its contribution to the knowledge of comparative avian anatomy up to genotype level, has also established a comparative baseline data for further comparative gross and morphometric reproductive studies in these genotypes of Nigerian local chickens.

\section{Acknowledgements}

None.

\section{Conflict of interest}

Author declares that there is no conflict of interest.

\section{References}

1. Momoh OM, Ehiobu NG, Nwosu, CC. Egg production of two Nigerian local chicken ecotypes under improved management. Proceedings $32^{\text {nd }}$ Annual conference of Nigerian Society for Animal Production. March 8-22, University of Calabar, Nigeria; 2007. p. 278-281.

2. Wimmers K, Ponsuksili S, Hardge T, et al. Genetic distinctness of African, Asian and South American local chickens. Anim Genet. 2000;31(3):159-165.

3. Ebozoje MO, Ikeobi CON. Productive performance and occurrence of Major genes in the Nigerian local chicken. Nigerian Journal of Genetics. 1995;10:67-77.

4. Udoh UH, Okon B, Udoh AP. Egg Quality Characteristics, Phenotypic Correlations and Prediction of Egg Weight in Three (Naked Neck, Frizzled Feather and Normal Feathered) Nigerian Local Chickens. International Journal of Poultry Science. 2012;11(11):696-699.

5. Ojedapo LO, Adedeji TA, Ameen, SA, et al. Effects of strain and age on egg quality characteristics of two different strains of layer chickens kept in cages in Derived Savannah Zone of Nigeria. Proceedings of 14th Annual Conference, Animal Science Association of Nigeria. Ogbomoso; 2009:42-43 p.

6. Saino NP, Dallara R, Martinelli, et al. Early maternal effects and antibacterial immune factors in the eggs, nestlings and adults of the barn swallow. Journal of Evolutionary Biology. 2002;15(5):735-743.

7. Bradley OC, Grahame T. The Structure of the Fowl. Edinburgh: Oliver and Boyd; 1960.

8. Fitzgerald TC. The Coturnix Quail Anatomy and Histology. Ames, Iowa: The Iowa State University Press; 1969. p. 225-255

9. Peters SO, Ikeobi CON, Ozoje MO, et al. Genetic variation in the reproductive performance of the Nigerian indigenous chicken. Tropical Animal Production and Investment. 2002;5:37-46.

10. Peters SO, Ikeobi, CON, Ozoje MO, et al. Modellling Growth in Seven chicken genotypes. Nigerian Journal of Animal Production. 2005;32:28-38.

11. Peters SO, Shoyebo OO, Ilori, BM, et al. Semen quality traits of seven strains of chickens raised in the humid tropics. International Journal of Poultry Science. 2008;7(10):949-953.

12. Peters SO, Shoyebo OO, Ilori, BM, et al. Gene segregation effects on fertility and hatchability of pure and crossbred chicken genotypes in the humid tropics. International Journal of Poultry Science. 2008;7:954-958.

13. Wekhe SN. Susceptibility of indigenous (Nigerian) and exotic (Harco) chickens to fowl typhoid infection. Tropical Veterinarian. 1992;10:1-2.

14. Google Maps. 2015.

15. Wilson GW. Wilson's Practical Meat Inspection. 7th ed. USA: Blackwell Publishing; 2005. 82p.

16. Khokhlov RY, Kuznetcov SI. Morphogenesis of a Tunica Mucosa of Oviduct of the Hens. International Journal of Morphology. $2007 ; 25(2): 329-333$

17. Romanoff AL, Romanoff AJ. The avian egg. New York: John Wiley \& Sons; 1949.

18. Kinsky FC. The consistent presence of paired ovaries in the Kiwi (Aptry) with some discussion of this condition in other birds. Journal of Ornithology. 1971;112(3):334-335.

19. Pollock CG, Orosz SE. Avian reproductive, anatomy physiology and endocrinology. Veterinary Clinical Exotica. 2002;5(3):441-474. 
20. Sharaf ASM. Some histological and Histochemical on the ostrich oviduct at different ages. MSc Thesis, Zagazig University. 2005.

21. Moraes C, BaraldiArtoni SM, Pacheco MR, et al. Morphology and histology of the oviduct of Marrecas Anaboschas. Arq Brasilian Veterinary Medicine and Zoological Technology. 2010;62(2):34-44.

22. Vijayakumar K, Balasundaram K, Paramasivan S, et al. Macro anatomy of Female Reproductive Tract during Laying and Non-Laying Period in Adult Emu Birds (Dromaius Novaehollandiae). Asian Journal of Science and Technology. 2014;5(12):793-795.

23. Fujii S. Histological and histochemical studies on the oviduct of the domestic fowl with special reference to the region of utero-vaginal juncture. Arch Histol Jpn. 1963;23:447-459.

24. Rao TSC. Microanatomical studies on the reproductive system of the domestic duck (AnasBoschasdomesticus). Tamil Nadu Veterinary and Animal Sciences University, India; 1994.

25. Nickel R, Schummer A, Seiferle E. Anatomy of the domestic birds Germany: Verlag Paul Parey; 1977. 201p.

26. Al-Karkhy, Mohammed KH. Anatomical and Histological study of the oviduct in the Iraqi Breed Geese (Anseranser). A Thesis submitted to College of Veterinary Medicine, Baghdad University, Iraq; 2010.

27. Parto P, Zabihollah K, Abbas A, et al. The Microstructure of Oviduct in Laying Turkey Hen as Observed by Light and Scanning Electron Microscopies. World Journal of Zoology. 2011;6(2):120-125.

28. Ferdous KA, Parvez MNH, Rahman MT. Effects of age on growth and development of vagina in ISA Brown chickens. The Bangladesh Veterinarian. 2011;28(2):75-79.

29. Parizzi RC, Santos JM, Oliveira MF, et al. Macroscopic and Microscopic Anatomy of the Oviduct in the Sexually Mature Rhea. Anat Histol Embryol. 2008;37:169-176.

30. King A, Mclelland J. Female reproductive system. Birds: Their structure and function. 2nd ed. London: Bailliers \& Tindall; 1984. p. 145-165.

31. Bakst MR. Structure of the avian oviduct with emphasis on sperm storage in poultry. J Exp Zool. 1998;282(4-5):618-626.

32. Drenowatz C, Elrod C. The Ratite Encyclopedia. Ratite records, San Antonio, USA; 1995.
33. Fowler ME. Comparative clinical anatomy of ratites. Journal of Zoology and Wildlife Medicine. 1991;22(2):204-227.

34. Bakst MR, Akuffo V. Morphology of the turkey vagina with and without an egg mass in the uterus. Poult Sci. 2009;88(3):631-635.

35. Mohammadpour AA, Zamanimoghadam A, Heidari M. Comparative histo morphometrical study of genital tract in adult laying hen and duck. Vet Res Forum. 2012;3(1):27-30.

36. Peters SO, Olusegun MOI, Brilliant OA, et al. Genotype and Sex Effect on Gastrointestinal Nutrient Content, Microflora and Carcass Traits in Nigerian Native Chickens. International Journal of Poultry Science. 2010;9(8):731-737.

37. Okpe GC, Nwatu U, Anya K. Morphometric Study of the Testes of the Nigerian Local Breed of Chicken. Animal Research International. 2010;7(2):1163-1168.

38. Mekonnen H, Kelay B, Berhan T, et al. Assessment of nutritional status of indigenous scavenging chickens in Ada'a district, Ethiopia. Trop Anim Health Prod. 2010;42(1):123-130.

39. Gueye EF. Village egg and fowl meat production in Africa. World's Poultry Science Journal. 1998;54(1):73-86.

40. Aini I. Diseases in rural family chickens in South East Asia. In: The First International Network for Family Poultry Development (INFPD). Electronic Conferences on the Scope and Effect of Family Poultry Research and Development, FA. 1999.

41. Simmons GS, Hetzel DJS. Time relationship between oviposition ovulation and egg formation in (Khaki Campbell ducks). British Poultry Science. 1983;24(1):21-25.

42. Ma RCS. The time of release of the luteinizing hormone from the adeno-hypophysis of laying domestic ducks. Poultry Science. 1968;47(2):404-410

43. Mishra D, Sultana N, Masum MA, et al. Gross and Histomorphologica Studies of the Oviduct of Native Chicken of Bangladesh. Bangladesh Journal of Veterinary Medicine. 2014;12(1):9-15.

44. Verma OP, Cherms, FL. Observation on the oviduct of turkeys. Avian Disease. 1964;8(1):19-26. 